\title{
High-Resolution, In Situ Monitoring of Stable Isotopes of Water Revealed Insight into Hydrological Response Behavior
}

\author{
Amir Sahraei ${ }^{1, *}$, Philipp Kraft ${ }^{1}$, David Windhorst ${ }^{1}$ and Lutz Breuer ${ }^{1,2}{ }^{(D)}$ \\ 1 Institute for Landscape Ecology and Resources Management (ILR), Research Centre for BioSystems, \\ Land Use and Nutrition (iFZ), Justus Liebig University Giessen, 35392 Giessen, Germany; \\ philipp.kraft@umwelt.uni-giessen.de (P.K.); david.windhorst@umwelt.uni-giessen.de (D.W.); \\ Lutz.Breuer@umwelt.uni-giessen.de (L.B.) \\ 2 Centre for International Development and Environmental Research (ZEU), Justus Liebig University Giessen, \\ Senckenbergstrasse 3, 35390 Giessen, Germany \\ * Correspondence: amirhossein.sahraei@umwelt.uni-giessen.de; Tel.: +49-641-99-37395
}

Received: 20 January 2020; Accepted: 13 February 2020; Published: 18 February 2020

\begin{abstract}
High temporal resolution (20-min intervals) measurements of stable isotopes from groundwater, stream water and precipitation were investigated to understand the hydrological response behavior and control of precipitation and antecedent wetness conditions on runoff generation. Data of 20 precipitation events were collected by a self-sufficient mobile system for in situ measurements over four months in the Schwingbach Environmental Observatory (SEO, temperate climate), Germany. Isotopic hydrograph separation indicated that more than $79 \%$ of the runoff consisted of pre-event water. Short response times of maximum event water fractions in stream water and groundwater revealed that shallow subsurface flow pathways rapidly delivered water to the stream. Macropore and soil pipe networks along relatively flat areas in stream banks were likely relevant pathways for the rapid transmission of water. Event water contribution increased with increasing precipitation amount. Pre-event water contribution was moderately affected by precipitation, whereas, the antecedent wetness conditions were not strong enough to influence pre-event water contribution. The response time was controlled by mean precipitation intensity. A two-phase system was identified, at which the response times of stream water and groundwater decreased after reaching a threshold of mean precipitation intensity of $0.5 \mathrm{~mm} \mathrm{~h}^{-1}$. Our results suggest that high temporal resolution measurements of stable isotopes of multiple water sources combined with hydrometrics improve the understanding of the hydrological response behavior and runoff generation mechanisms.
\end{abstract}

Keywords: stable isotopes of water; high-resolution data; hydrological response; hydrograph separation; runoff components; maximum event water fraction; response time; runoff generation

\section{Introduction}

Understanding the response of runoff components to precipitation and its controlling factors gives insight into runoff generation mechanisms. Total runoff responds to incoming precipitation via event water or pre-event water, the latter being water stored in the catchment prior to the onset of precipitation [1]. The fraction of event and pre-event water in total runoff and the timing of its responses may vary depending on the controlling factors such as topography, land use, precipitation, and antecedent wetness characteristics.

The use of stable isotopes of water $\left(\delta^{18} \mathrm{O}\right.$ and $\left.\delta^{2} \mathrm{H}\right)$ and other conservative tracers in tracer-based hydrograph separation techniques enables the differentiation of source components of event and 
pre-event water and provides the opportunity to evaluate its controlling factors [1]. Several studies investigated the correlation of event and pre-event water contribution with topographical, land use, precipitation, and antecedent wetness characteristics. Shanley et al. [2] noted that event water contribution correlated positively with catchment size and open land cover. Šanda et al. [3] addressed the influence of land use on pre-event water contribution. They found that the pre-event water contribution decreased with increasing forest cover, particularly due to the retention of water via interception and transpiration losses of soil water. Several studies reported a positive correlation between precipitation amount and event water contribution [4-7]. In contrast, Renshaw et al. [8] showed a positive correlation between pre-event water contribution and precipitation amount, but only during peak discharge. Generally, wetter antecedent conditions result in an increase of pre-event water contribution, as they increase the connectivity of contributing areas $[4,5,7,9,10]$. In contrast to those findings, Shanley et al. [2] described positive correlations between antecedent wetness conditions and event water contribution. They hypothesized that infiltration must first fill storage deficits before event water can be rapidly transported via lateral flow pathways to stream. Response times (i.e., the time lag between the first detection of precipitation and maximum event water fraction) and their controlling factors have been only scarcely investigated, without finding a consensus [5,11]. McGlynn et al. [11] observed that response times increased with catchment size, whereas James and Roulet [5] reported no strong correlation of response times with catchment characteristics. The latter work focused on small, forested headwater catchments. In such catchments, the canopy could possibly buffer the incoming precipitation signal. Another likely explanation is that different response times of groundwater blur the land use signal.

Most of the previous isotope-based studies dealing with the investigation of catchment responses used daily to monthly data, at which the fine-scale response behavior of runoff components is overlooked. Kirchner et al. [12] noted that a sampling period longer than the hydrological response time of a catchment might lead to a significant loss of information. Only a few studies employed high temporal resolution sampling (i.e., sub-daily) of stable isotopes of water [5-7,11,13]. However, these studies are limited to sampling a low number of water sources, i.e., mainly stream water and precipitation.

Manual high-resolution, multiple-source sampling is restricted to short durations and might fail in the sampling of relevant events due to their erratic and difficult-to-plan nature. Therefore, a few groups developed and utilized automatic sampling and analytical systems for in situ monitoring recently to overcome these problems [13-15]. Such systems allow gaining insight into previously unknown hydrological dynamics. Von Freyberg et al. [13] sampled stable water isotopes of stream water and precipitation every $30 \mathrm{~min}$ to estimate event water fractions of eight precipitation events using hydrograph separation. However, their study is limited to sampling two water sources, i.e., stream water and precipitation. Heinz et al. [14] presented the technical setup of an automated sampling system and provided an initial proof-of-concept to monitor multiple water sources (surface water and groundwater) in up to ten rice paddies of a field trial in the Philippines. Building on this system, Mahindawansha et al. [15] investigated seasonal and crop effects on isotopic compositions of surface water and groundwater in these rice paddies. An important, yet poorly known mechanism is the response of several water sources in real catchments, including that of shallow groundwater to precipitation.

Here we report about a newly developed system for high temporal resolution sampling of multiple sources, including groundwater, stream water, and precipitation. Previous studies in the Schwingbach catchment reported a fast response of the system to precipitation inputs [16,17]. They found that shallow groundwater head levels and streamflow responded rapidly to precipitation inputs. However, no obvious response was observed by Orlowski et al. [17] in isotopic compositions of stream water and groundwater, potentially due to a rather coarse weekly sampling resolution. We, therefore, measured stable isotope composition of water in high temporal resolution (20-min) and of various sources. Sources included two stream sections, three different groundwater sources and precipitation. In order 
to investigate the hydrological response behavior and the role of controlling factors on the runoff generation process, we used a new, trailer-based mobile automatic sampling system for high-resolution water quality analysis. In particular, we studied the following objectives:

I. Investigation if the short-term response behavior observed in the previous studies in the Schwingbach Environmental Observatory (SEO), is reflected in isotopic signatures of stream water and groundwater.

II. Estimation of event-based contribution of event and pre-event water to total runoff.

III. Quantification of the event-based response time of maximum event water fraction in stream water and groundwater.

IV. Evaluation of the role of precipitation and antecedent wetness conditions as drivers of event and pre-event water contribution and response time.

\section{Materials and Methods}

\subsection{Study Area}

The study was conducted in the headwater catchment of the Schwingbach Environmental Observatory (SEO) in Hesse, Germany (Figure 1a-c). The $1.03 \mathrm{~km}^{2}$ catchment area is covered by $76 \%$ forests, $15 \%$ arable land, and $7 \%$ meadows, mainly found along the small perennial Schwingbach stream. The elevation ranges from $310 \mathrm{~m}$ in the north to $415 \mathrm{~m}$ a.s.l. in the south. The climate is temperate oceanic (Köppen climate classification), with a mean annual air temperature of $10.1{ }^{\circ} \mathrm{C}$ and total annual precipitation of $452 \mathrm{~mm}$ in the year 2018. Our study took place from August 8th to December 9th in 2018, which was an unusually dry and warm year [18]. Soil types and geology are similar to the neighboring valley of the Vollnkirchner Bach [16]. Cambisols dominate on forests stands, whereas Stagnosols are mainly found on arable land. Under the forests, the soil texture is dominated by silt, fine sand and gravel at 0 to $3 \mathrm{~m}$ depths, with low clay content between 0.6 and $3 \mathrm{~m}$ depths. Soils lay on slightly weathered clay shale bedrock. Under meadows and arable land, the soil texture is rich in silt and fine sand ( $0-5 \mathrm{~m}$ depths) with small amounts of clay and gravel between 0.8 and $5 \mathrm{~m}$ depths. Here, soils developed on greywacke and weathered clay shale.

An automatic climate station (AQ5, Campbell Scientific Inc., Shepshed, UK) operated with a CR1000 data logger measured precipitation depth and air temperature at $5 \mathrm{~min}$ intervals. Groundwater (GW) table depth was manually measured biweekly to obtain an estimate of the groundwater depth in the unconfined aquifer over the year. The mean groundwater table depth (i.e., mean of biweekly measurements) from November 2017 to September 2018 was $0.44 \pm 0.33 \mathrm{~m}$ (mean \pm standard deviation), $0.48 \pm 0.33 \mathrm{~m}$ and $1.41 \pm 0.48 \mathrm{~m}$ for GW1, GW2, and GW3, respectively. A stream gauge at SW2 (RBC flume, Eijkelkamp Agrisearch Equipment, Giesbeek, Netherlands) equipped with a pressure transducer (Micro-Diver, Eigenbrodt Inc., Königsmoor, Germany) automatically recorded water levels at $10 \mathrm{~min}$ intervals. The transducer readings were calibrated against manual measurements and continuous discharge was derived through the calibrated stage-discharge relationship of the RBC flume provided by the manufacturer [19]. The discharge was converted to $\mathrm{mm} \mathrm{h}^{-1}$ (i.e., divided by the area of the catchment) to allow for a direct comparison with precipitation in the same unit. Two remote telemetry loggers (A753, Adcon, Klosterneuburg, Austria), one installed at the toeslope (ST) and one at the footslope (SF), were equipped with sensors (ECH2O 5TE, METER Environment, Pullman, USA) to measure soil moisture at 5,30 , and $70 \mathrm{~cm}$ soil depths, representing the densely rooted organic horizon, the topsoil, and subsoil, at 5 min intervals. 


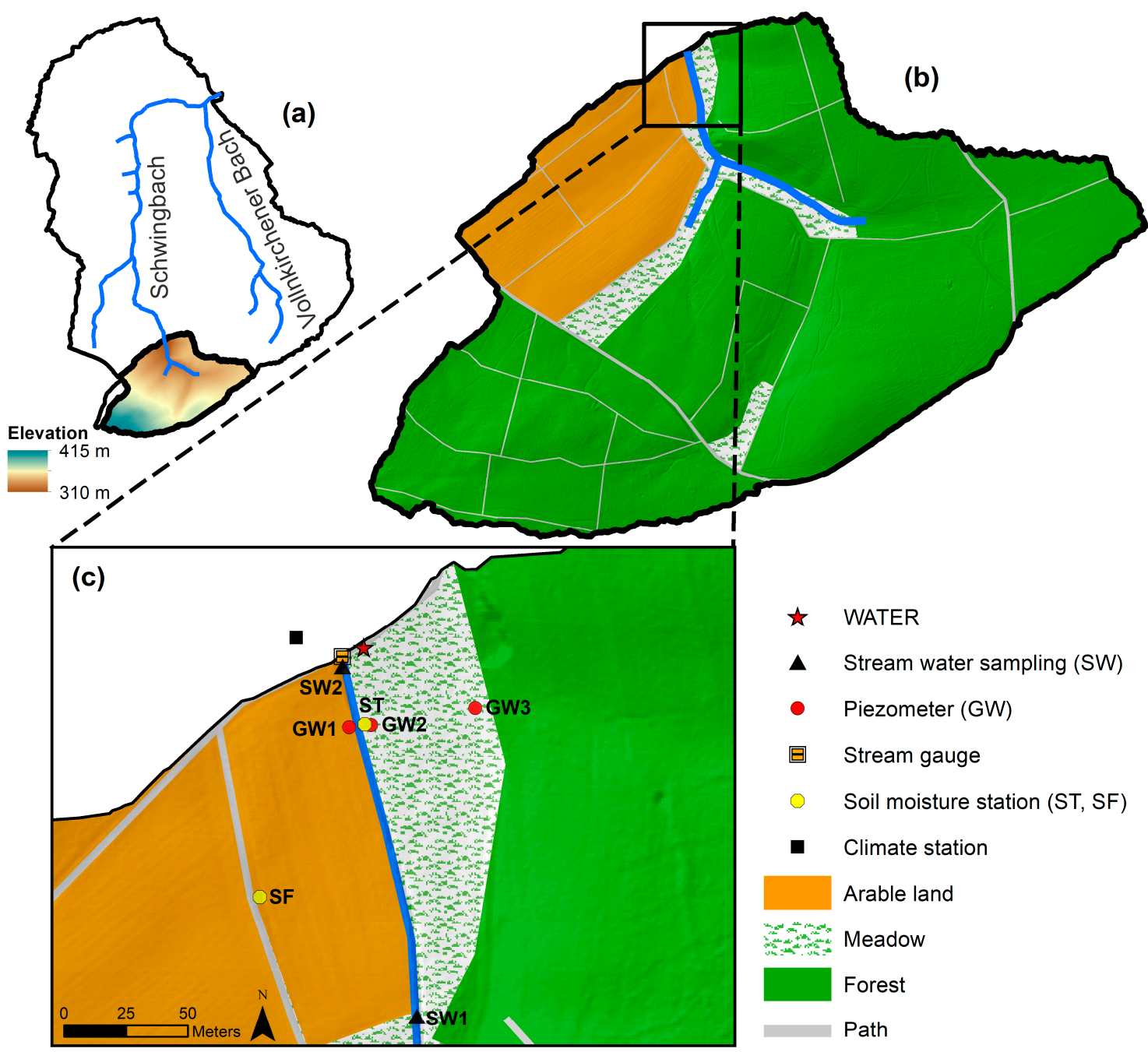

Figure 1. (a) Schwingbach Environmental Observatory (SEO), (b) Study area in the Schwingbach headwater and (c) Measuring network along the stream reach of the Schwingbach headwater. ST and SF are the soil moisture stations at the toeslope and footslope, respectively.

\subsection{Water Analysis Trailer for Environmental Research (WATER)}

A custom-made, automated mobile laboratory, the Water Analysis Trailer for Environmental Research (WATER), was utilized to automatically sample multiple water sources (e.g., stream water, groundwater, and precipitation) and analyze the stable isotopes of water $\left(\delta^{18} \mathrm{O}\right.$ and $\left.\delta^{2} \mathrm{H}\right)$ and water chemistry in situ (Figure 2). Constructing the trailer was based on previous experiences made by Heinz et al. [14] and Mahindawansha et al. [15]. Figure 3 illustrates the technical set up of the WATER. The automatic sampling system allows us to sample up to 12 water sources. A peristaltic pump (M1500, Verder $\mathrm{GmbH}$, Haan, Germany) draws water from the sources and delivers it through a $5 \mu \mathrm{m}$ polyester membrane (polyester filter, Pieper Filter GmbH, Germany) to a $1000 \mathrm{~mL}$ sample reservoir, which is connected to a continuous water sampler (CWS) (A0217, Picarro Inc., Santa Clara, USA), coupled to a wavelength-scanned cavity ring-down spectrometer (WS-CRDS) (L2130-i, Picarro Inc., Santa Clara, USA) to analyze the water's isotopic composition. The deployment of the Picarro A0217 and L2130-i requires the supply of at least two standard water samples with a known isotopic signature. We used heavy $\left(+3.13 \%\right.$ or for $\delta^{18} \mathrm{O}$ and $-1.52 \%$ o for $\left.\delta^{2} \mathrm{H}\right)$ and light $\left(-22.43 \%\right.$ o for $\delta^{18} \mathrm{O}$ and $-164.60 \%$ o for $\left.\delta^{2} \mathrm{H}\right)$ standard water samples, which were calibrated via a WS-CRDS (precision of $0.02 \%$ o for $\delta^{18} \mathrm{O}$ and $0.18 \%$ o for $\delta^{2} \mathrm{H}$ ) at the laboratory of the Institute for Landscape Ecology and Resources Management at the Justus Liebig University Giessen, Germany. To prevent the isotope analyzer from falling dry 
between switching the samples, a backup reservoir is installed. A $10 \mathrm{~L}$ bucket filled with deionized water flushes the system between the sampling cycles. A $5 \mathrm{~L}$ bucket filled by precipitation falling on a funnel-type $3.3 \mathrm{~m}^{2}$ tarp is connected to the WATER for automatic sampling (Figure 2). The bucket is equipped with a sensor (tank electrode, Votronic $\mathrm{GmbH}$, Lauterbach, Germany) to monitor the amount of the collected precipitation inside the bucket.

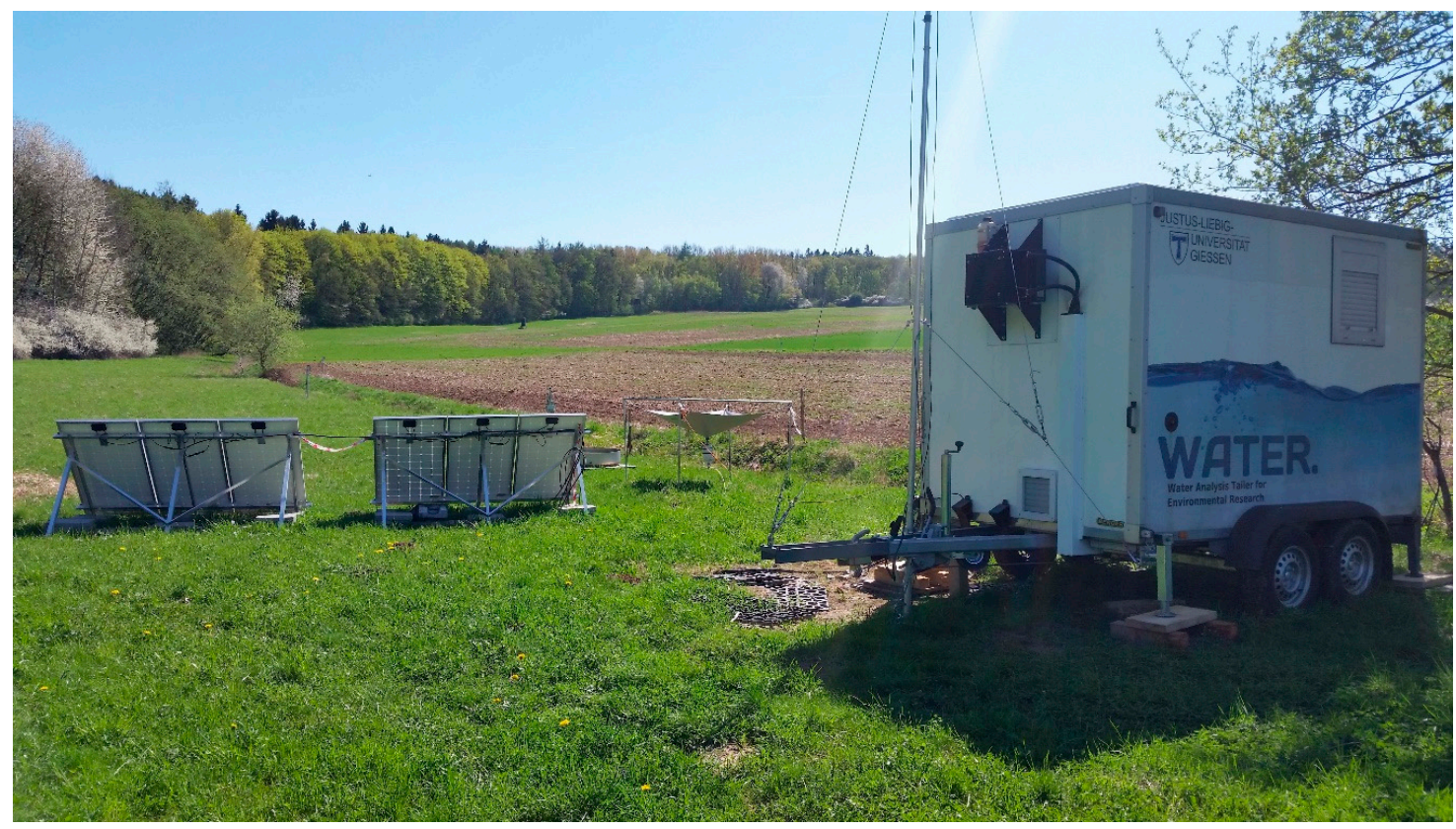

Figure 2. Water Analysis Trailer for Environmental Research (WATER) (right), two solar panels supporting power supply (left) and the funnel-type tarp for collection of precipitation (further back in the middle) installed in the Schwingbach Environmental Observatory (SEO), Hesse (Germany).

The WS-CRDS measured the isotopic composition of water vapor every $1.7 \mathrm{~s}$. Due to the carry-over effects within the CWS, it took approximately $10 \mathrm{~min}$ until a steady isotope signal was reached. We averaged the last $3 \mathrm{~min}$ of the following $10 \mathrm{~min}$ sampling period to report the final isotope values. The overall sampling interval per sample summed up to $20 \mathrm{~min}$. To minimize the carry-over effect, the sample reservoir was automatically rinsed with $60 \mathrm{~mL}$ sample water, emptied and again filled with $60 \mathrm{~mL}$ water to be analyzed. Results are reported in (\%o) for $\delta^{18} \mathrm{O}$ and $\delta^{2} \mathrm{H}$ relative to the Vienna Standard Mean Ocean Water (VSMOW).

Further analytical instruments of the WATER (Figure 3) measure water quality parameters such as electrical conductivity, $\mathrm{pH}$, and water temperature (via multi-parameter water quality probe, YSI600R, YSI Inc., Yellow Springs, USA) and $\mathrm{NO}_{3}, \mathrm{DOC}$, TOC, and total suspended sediments via UV spectrometry (ProPS, Trios GmbH, Rastede, Germany). Results from water quality analysis are not reported in this study.

An in-house developed software written in Python runs on an industry PC (NISE 101, SEPCTRA, Reutlingen, Germany) with the Ubuntu Mate operation system to control the sampling scheme and the delivery system, as well as to store results and communicate with the WATER. The measurement processes are controlled by a programmable logic controller (WAGO-I/O-SYSTEM 750, WAGO Kontakttechnik $\mathrm{GmbH}$, Minden, Germany). Raw data is stored every 5 min and automatically uploaded to a web-database for visualization, post-processing, and storage. Alarm messages (e.g., a low fuel gauge or system failure) are automatically triggered by SMS. A diesel backup-generator (with $5 \mathrm{~kW}$ peak), a Lithium-ion buffer battery $(7.2 \mathrm{kWh}$ ), and two solar panels (with $1.7 \mathrm{~kW}$ peak) (Figure 2) supply the AC and DC power of the system and allow the system to support a continuous load of approximately $400 \mathrm{~W}$. 


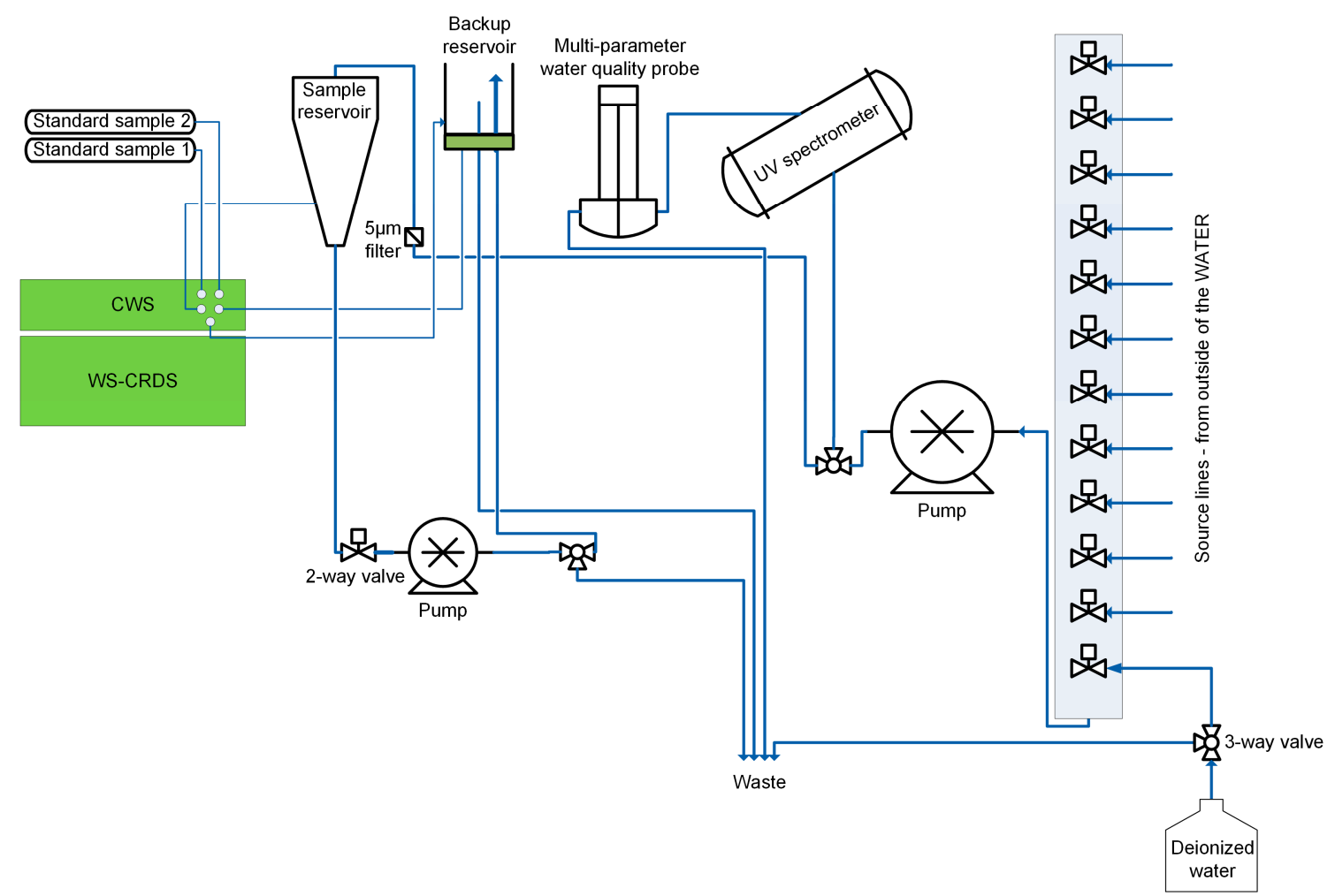

Figure 3. Schematic of the sampling board and analytical instrumentation inside the Water Analysis Trailer for Environmental Research (WATER). CWS = continuous water sampler, WS-CRDS = wavelength-scanned cavity ring-down spectrometer.

\subsection{Sampling Schedule}

In the setup of this project, the WATER sampled automatically from two stream water sources (SW1 and SW2), three groundwater sources (GW1, GW2 and GW3), and one precipitation bucket (Figures 1c and 2). SW1 was sampled approximately $145 \mathrm{~m}$ upstream of the WATER at the edge of arable land and water from SW2 was taken next to the location of the WATER. Shallow groundwater was sampled from piezometers made from perforated PVC tubes sealed with bentonite clay at the upper part of the tube to prevent contamination by surface water. Piezometers of GW1 and GW2 were located at the toeslope on arable land and the meadow, respectively. The piezometer of GW3 was installed at the footslope at the edge of the forest.

Given the sampling resolution of $20 \mathrm{~min}$, the setup of the system allowed the measurement of 72 samples per day. The sampling cycle was scheduled to sample $n=16$ (with $n$ the number of samples) for each stream water source, $n=8$ for each groundwater source and $n=8$ for each standard water sample in case of no precipitation event. In the case of a precipitation event, the sampler automatically took a precipitation sample whenever the sample volume exceeded $1 \mathrm{~L}(0.3 \mathrm{~mm})$ inside the precipitation bucket. After sampling, the precipitation bucket was emptied to avoid carry-over effects, and the sampler was blocked for $60 \mathrm{~min}$, allowing us to take samples from other sources.

\subsection{Event Definition and Characteristics}

We analyzed autocorrelation for time series of precipitation depth measured over the sampling period to define independent precipitation events [20,21]. A plot of the correlation coefficient with respect to the lag time indicated the minimum lag time, for which the autocorrelation coefficient was close to zero. This lag time defined the minimum inter-event time, at which the precipitation events were considered independent. The autocorrelation plot for the precipitation depth at 5 min intervals (Figure 4) shows that correlation coefficients begin to level off close to zero at $5.7 \mathrm{~h}$. We, therefore, 
considered precipitation events as independent if the inter-event time exceeded $6 \mathrm{~h}$. In total, 20 events were selected, at which the application of hydrograph separation was possible due to the availability of isotope concentration data of precipitation, stream water, and groundwater. The beginning of an event was defined as the onset of precipitation and the end of an event as the time when $\frac{Q_{e_{i}}}{Q_{e_{\max }}} \leq 0.05$ (i.e., when the fraction of event water relative to its maximum value reached $5 \%$ or less) or when a new event began, whichever happened first.

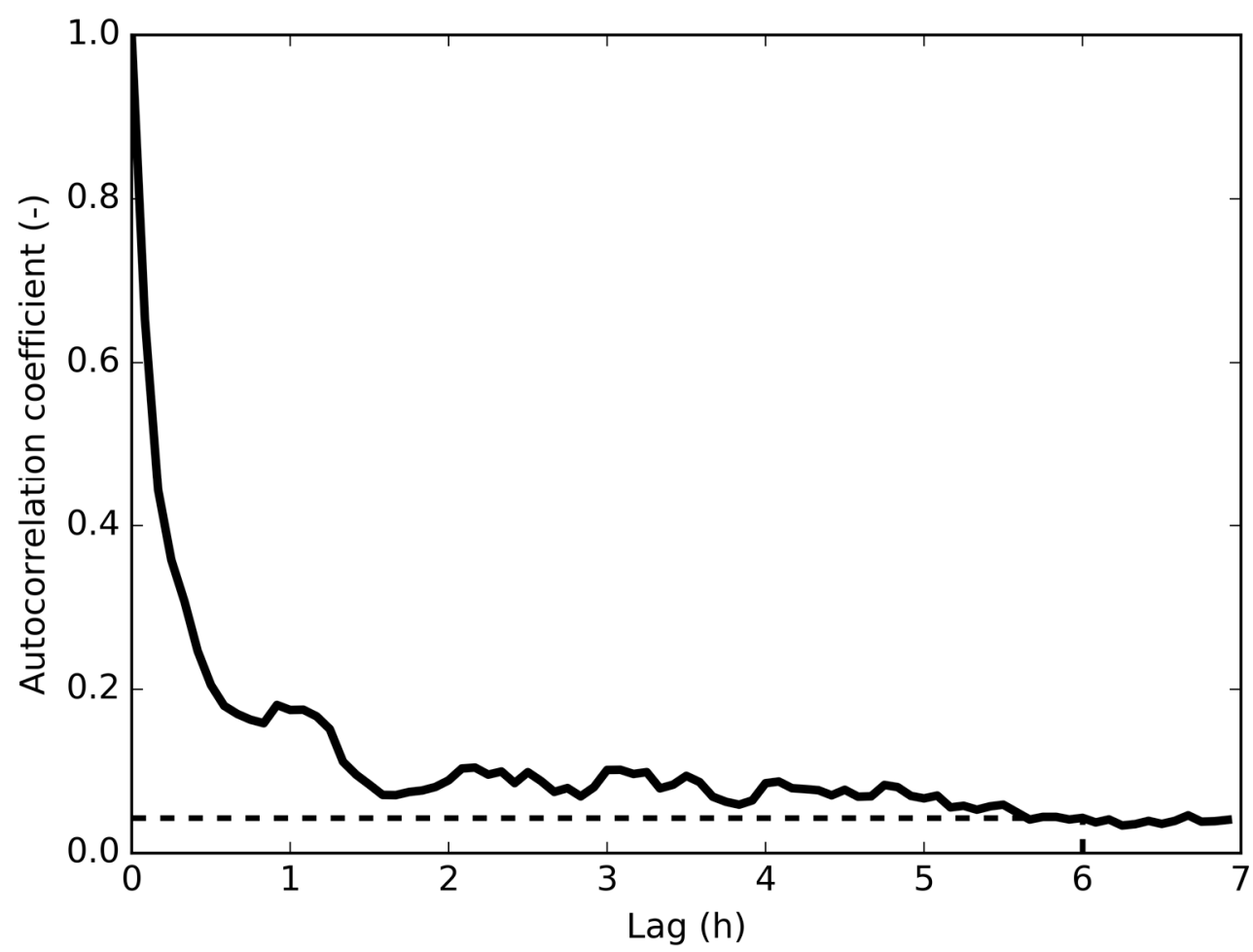

Figure 4. Autocorrelation plot for the precipitation depth at $5 \mathrm{~min}$ intervals. The precipitation events were considered independent if the inter-event time exceeded $6 \mathrm{~h}$.

We calculated a number of hydrometrics to describe precipitation, antecedent wetness, and response characteristics of each event (Table 1). A Spearman rank correlation $(p)$ analysis was used to assess the control of precipitation and antecedent wetness hydrometrics on response characteristics. The correlation values were considered statistically significant if $p<0.05$. We described strength of the correlation strong if $p \geq 0.7$, moderate if $0.4<p<0.7$, and weak if $p \leq 0.4$.

Table 1. Hydrometrics to describe precipitation, antecedent wetness, discharge characteristics, maximum event water fraction, and response time for each event.

\begin{tabular}{ccc}
\hline Metric & Description & Unit \\
\hline Precipitation & & \\
\hline$P$ & Total precipitation per event & $\mathrm{mm}$ \\
\hline$T$ & Precipitation duration & $\mathrm{h}$ \\
\hline$P_{\text {int }}$ & Mean precipitation intensity $\left(\frac{P}{T}\right)$ & $\mathrm{mm} \mathrm{h}^{-1}$ \\
\hline Antecedent Wetness & & \\
\hline$Q_{i n i}$ & $\begin{array}{c}\text { Initial discharge: } 1 \mathrm{~h} \text { averaged discharge } \\
\text { before onset of precipitation }\end{array}$ & $\mathrm{mm} \mathrm{h}^{-1}$ \\
\hline
\end{tabular}


Table 1. Cont.

\begin{tabular}{|c|c|c|}
\hline Metric & Description & Unit \\
\hline$S T 5_{i n i}, S T 30_{i n i}, S T 70_{i n i}$ & $\begin{array}{l}\text { Initial soil moisture: } 1 \mathrm{~h} \text { averaged soil } \\
\text { moisture before onset of precipitation at the } \\
\text { toeslope }(S T) \text { at } 5,30 \text { and } 70 \mathrm{~cm} \text { soil depths }\end{array}$ & $\%$ \\
\hline$S F 5_{i n i}, S F 30_{i n i}, S F 7_{i n i}$ & $\begin{array}{l}\text { Initial soil moisture: } 1 \mathrm{~h} \text { averaged soil } \\
\text { moisture before onset of precipitation at the } \\
\text { footslope }(S F) \text { at } 5,30 \text { and } 70 \mathrm{~cm} \text { soil depths }\end{array}$ & $\%$ \\
\hline \multicolumn{3}{|l|}{ Discharge } \\
\hline$Q_{\text {total }}$ & Total discharge volume per event & $\mathrm{mm}$ \\
\hline$Q_{e}$ & Total event water volume & $\mathrm{mm}$ \\
\hline$Q_{p e}$ & Total pre-event water volume & $\mathrm{mm}$ \\
\hline$\frac{Q_{\text {total }}}{P}$ & Runoff coefficient & $\%$ \\
\hline$\frac{Q_{e}}{Q_{\text {total }}}$ & Event water fraction in total runoff & $\%$ \\
\hline$\frac{Q_{p e}}{Q_{\text {total }}}$ & Pre-event water fraction in total runoff & $\%$ \\
\hline$F_{E_{\max }}$ & Maximum event water fraction & $\%$ \\
\hline$T_{F_{E_{\max }}}$ & $\begin{array}{l}\text { Response time: time lag between the first } \\
\text { detection of precipitation and the maximum } \\
\text { event water fraction }\end{array}$ & $\mathrm{h}$ \\
\hline
\end{tabular}

\subsection{Response Characteristics}

A two-component hydrograph separation (Equation (1)) was applied to quantify event-water fractions $F_{E}$ in stream water and groundwater sources using isotopic composition of stream water, groundwater, and precipitation:

$$
F_{E}=\frac{C_{S W / G W}-C_{p e}}{C_{e}-C_{p e}}
$$

$C_{S W / G W}, C_{e}$ and $C_{p e}$ are the isotopic concentrations in the sampling sources (i.e., stream water $S W$ and groundwater $G W$ ), event water (e) (i.e., precipitation) and pre-event (pe) water of sampling sources, respectively. $C_{p e}$ was calculated as the average of the last five samples before the onset of precipitation. $C_{e}$ is the incremental weighted mean of precipitation samples [22]. The maximum event water fractions $F_{E_{\max }}$ in stream water and groundwater were derived for each event at the time steps that resulted from the sampling schedule. The uncertainty of the event water fractions $W_{F_{E}}$ was quantified according to the Gaussian error propagation technique [23] (Equation (2)):

$$
W_{F_{E}}=\left\{\left[\frac{C_{e}-C_{S W / G W}}{\left(C_{e}-C_{p e}\right)^{2}} W_{C_{p e}}\right]^{2}+\left[\frac{C_{S W / G W}-C_{p e}}{\left(C_{e}-C_{p e}\right)^{2}} W_{C_{e}}\right]^{2}+\left[\frac{-1}{\left(C_{e}-C_{p e}\right)} W_{C_{S W / G W}}\right]^{2}\right\}^{\frac{1}{2}}
$$

$W_{C_{p e}}$ the uncertainty in pre-event water was estimated using the standard deviation of the last five measurements before the onset of precipitation. $W_{C_{e}}$, the uncertainty of the event water is the standard deviation of the incremental weighted mean of precipitation. $W_{C_{S W / G W}}$, the uncertainty in the sampling sources is the measurement precision of the CWS coupled to the WS-CRDS $\left(0.23 \%\right.$ o for $\delta^{18} \mathrm{O}$ and $0.57 \%$ o for $\delta^{2} \mathrm{H}$ ), which we derived from the standard deviation of measurements during the last $3 \mathrm{~min}$ of the sampling period of stream water and groundwater sources. The uncertainty of event water fractions was higher using $\delta^{18} \mathrm{O}$ measurements than those of $\delta^{2} \mathrm{H}$. Therefore, we performed an analysis based on the $\delta^{2} \mathrm{H}$ values only. 
We estimated the response time of the maximum event water fraction $T_{F_{E_{\max }}}$ in stream water and groundwater sources for each event. The response time was defined as the time lag between the first detection of precipitation and maximum event water fraction.

Total event water volume $Q_{e}$ (Equation (3)) and total pre-event water volume $Q_{p e}$ (Equation (4)) of each event were calculated from the event water fraction and discharge at each time step $i$ (hourly) as:

$$
\begin{gathered}
Q_{e}=\sum F_{E_{i}} \times Q_{i} \\
Q_{p e}=\sum\left(Q_{i}-Q_{e_{i}}\right)
\end{gathered}
$$

where $F_{E_{i}}, Q_{i}$ and $Q_{e_{i}}$ are the event water fraction in the stream water, the discharge recorded at the stream gauging site and the event water volume at time step $i$, respectively. In this study, we estimated $Q_{e_{i}}$ only for SW2 as stream discharge was only recorded at this site. Event water fractions $F_{E}$ were interpolated linearly with respect to time step $i . F_{E}$ values were also interpolated linearly between the measurement gaps that happened due to system maintenance. Following, the event water fraction in total runoff $\frac{Q_{e}}{Q_{\text {total }}}$, pre-event water fraction in total runoff $\frac{Q_{p e}}{Q_{\text {total }}}$ and the runoff coefficient $\frac{Q_{\text {total }}}{P}$ were calculated for each event.

\section{Results}

\subsection{Time Series of Isotopic and Hydrometric Observations}

The dynamics of precipitation, discharge, soil moisture as well as the $\delta^{2} \mathrm{H}$ of precipitation, stream water, and groundwater sources from August 8th to December 9th in 2018 are shown in Figure 5a-e. Over the sampling period, precipitation ranged between 0.01 and $3.71 \mathrm{~mm} \mathrm{~h}^{-1}$, and discharge between 0.0002 and $0.004 \mathrm{~mm} \mathrm{~h}^{-1}$ with the highest peak at event \#19. The discharge time series shows some distinct peaks, whereas diurnal variations in discharge resulted in a rather flickering behavior of the hydrograph. The discharge response pattern to precipitation during the sampling period partly matches the shallow soil moisture development at the toeslope and footslope. Measured soil moisture indicated generally wetter conditions at all three soil depths at the toeslope compared to the one at the footslope. Further, the temporal dynamics at the toeslope were also more pronounced, particularly at $5 \mathrm{~cm}$ soil depth. At both sites, the lowest soil moistures were recorded in late summer at $5 \mathrm{~cm}$ soil depth.

The values of $\delta^{2} \mathrm{H}$ in precipitation ranged from $-10.7 \%$ o to $-108.6 \%$ o with high within-storm event variation. From the beginning of the sampling period until early November, the values of $\delta^{2} \mathrm{H}$ in precipitation were heavier than those in stream water and groundwater, whereas they became significantly lighter over the remaining sampling period. Isotopic concentrations in stream water and groundwater (i.e., $C_{S W / G W}$ ) as well as in precipitation (i.e., $C_{e}$ ) were heavier than those in pre-event water (i.e., $C_{p e}$ ) until event 15 , whereas they became lighter thereafter. Over the entire sampling period, stream water and groundwater isotopes were almost stable. The mean values of $\delta^{2} \mathrm{H}$ for the stream sampling positions SW1 and SW2 were $-63.3 \pm 2.1 \%$ o (mean \pm standard deviation) and $-63.2 \pm 1.7 \%$, respectively. On average, GW1 $(-61.5 \pm 1.2 \%$ o) and GW2 $(-61.8 \pm 1.3 \%$ o $)$ at the toeslope depicted slightly heavier mean $\delta^{2} \mathrm{H}$ values compared to the GW3 at the footslope $(-63.3 \pm 1.2 \%$ o). Distinct responses to precipitation were observed in stream water as well as groundwater during events \#10, $\# 17$, and \#19. However, different response behaviors were found during events \#4 and \#7, at which stream water isotopes showed clear responses to precipitation, whereas a slight reaction could be observed in the groundwater isotopes. 
(a)

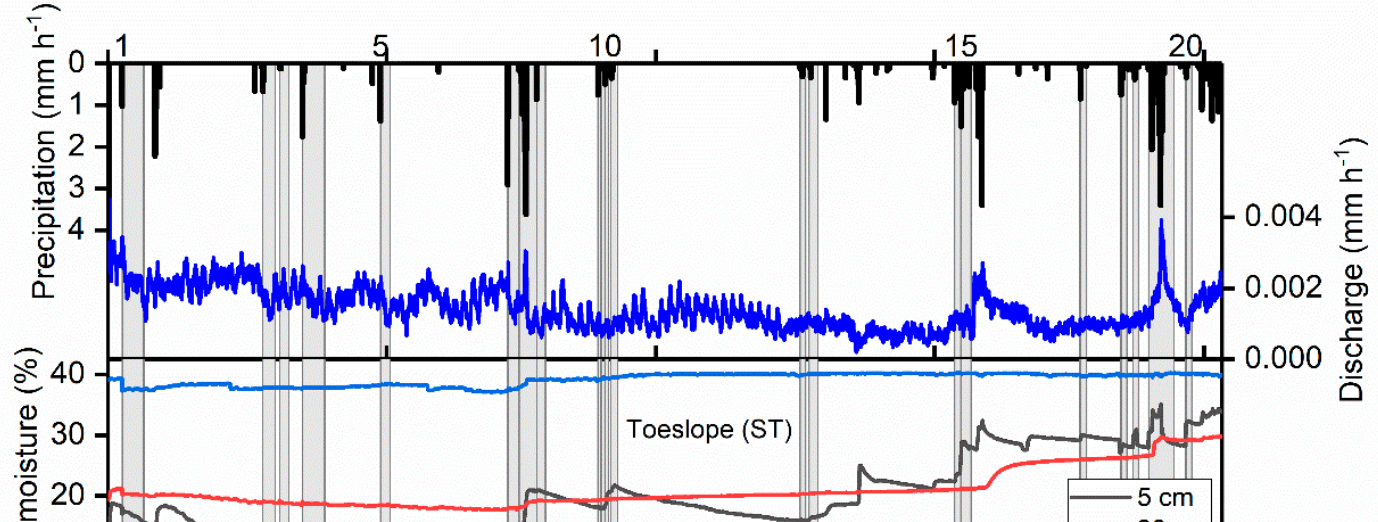

(c)

(b)

(d)

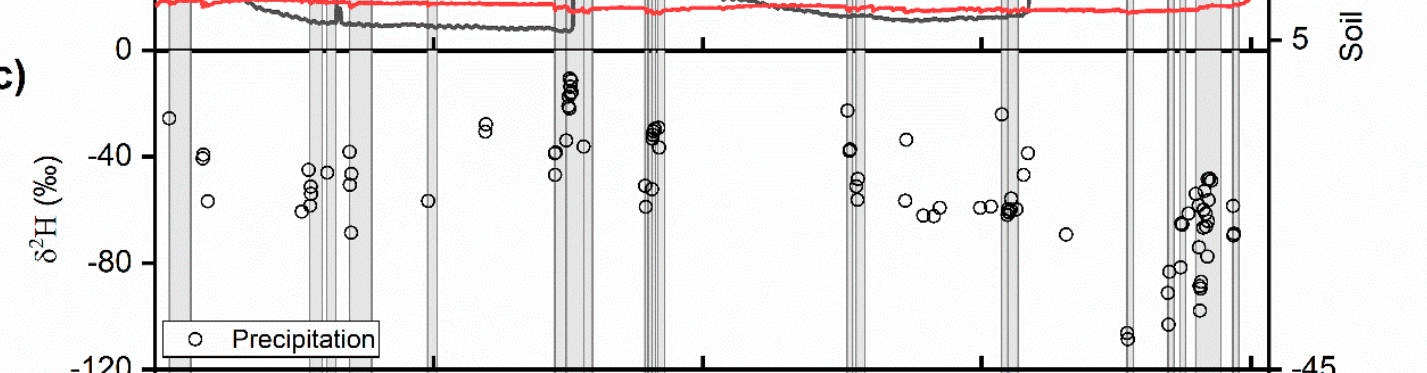

(e)

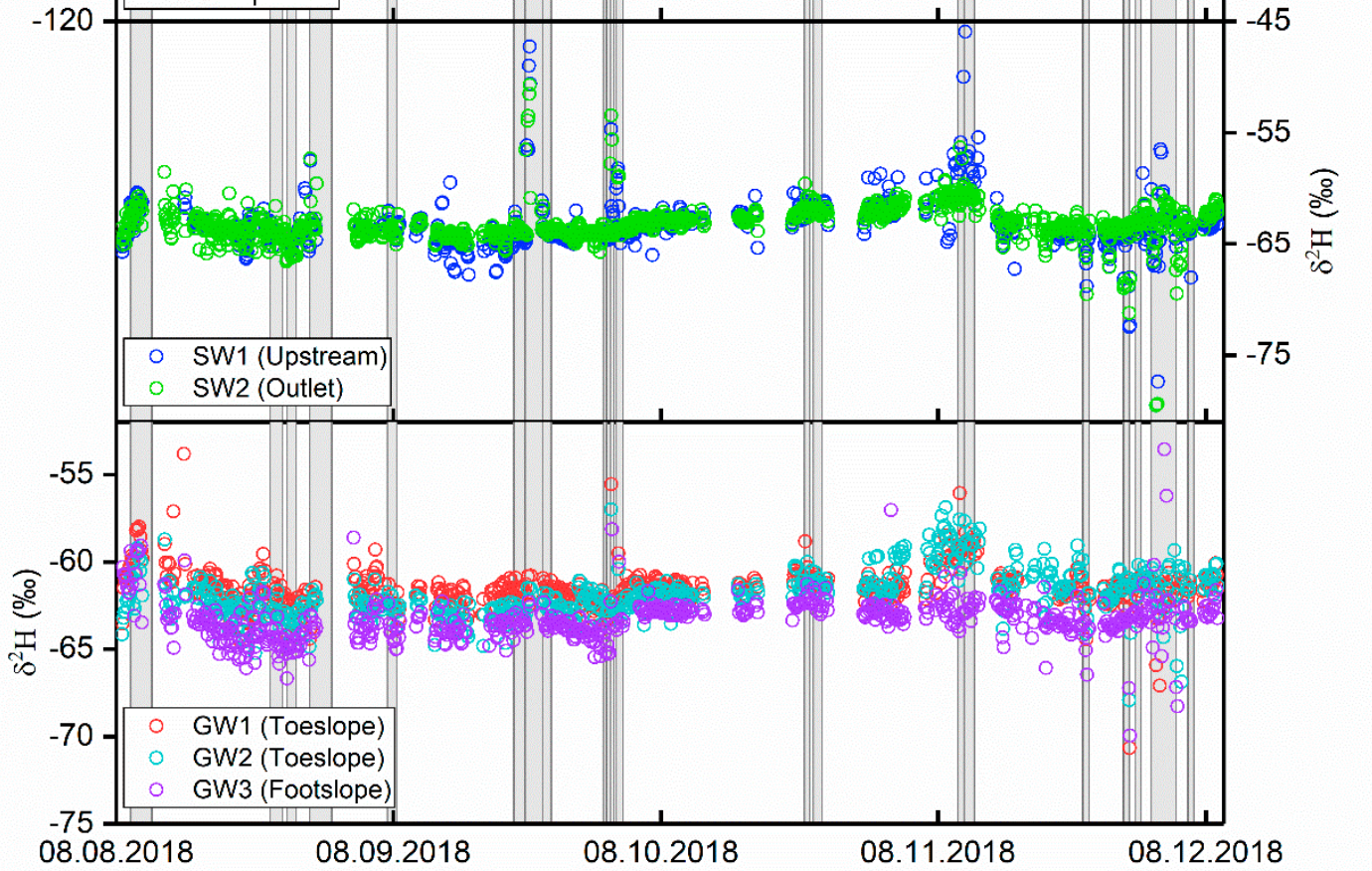

Figure 5. Time series of (a) precipitation and discharge, (b) soil moisture measured at 5, 30 and $70 \mathrm{~cm}$ depths at the toeslope and footslope, (c) $\delta^{2} \mathrm{H}$ in precipitation, (d) $\delta^{2} \mathrm{H}$ in stream water sources and (e) $\delta^{2} \mathrm{H}$ in groundwater water sources. The vertical grey bars indicate the 20 events. The numbers on top of panel (a) represent the event ID.

\subsection{Hydrometrics}

Hydrometrics of precipitation, antecedent wetness, and discharge characteristics, as well as maximum event water fraction, its uncertainty and response time of stream water and groundwater 
sources, were calculated for each of the 20 events (Tables S1-S3 in the Supplementary Materials). Figure $6 \mathrm{a}-\mathrm{f}$ shows the variation of the total precipitation, mean precipitation intensity, initial soil moisture in shallower layers (i.e., 5 and $30 \mathrm{~cm}$ ) at the toeslope and footslope, runoff coefficient, and event and pre-event water fraction in the total runoff for the 20 events. Total precipitation $P$ ranged between 0.3 and $19.6 \mathrm{~mm}(3.2 \pm 5.2 \mathrm{~mm}$, mean \pm standard deviation). The largest total precipitation was observed at event \#19 followed by event \#7 (Figure 6a). Mean precipitation intensity $P_{\text {int }}$ ranged between 0.1 and $6.1 \mathrm{~mm} \mathrm{~h}^{-1}\left(1.4 \pm 1.9 \mathrm{~mm} \mathrm{~h}^{-1}\right)$. Larger $P_{\text {int }}$ was observed among the first nine events, with the largest value at event \#1, followed by event \#5 and \#9 (Figure 6b).
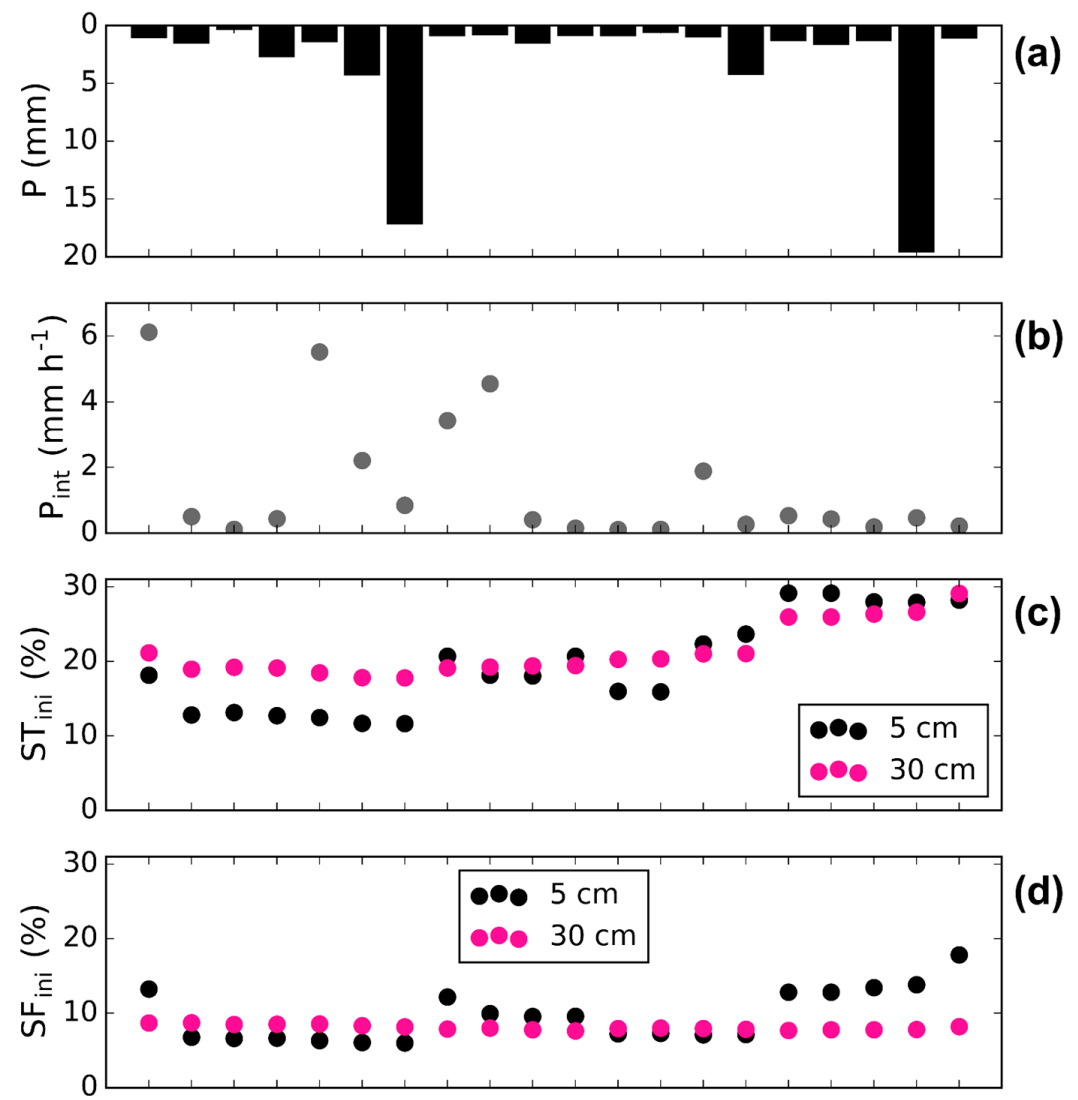

(d)

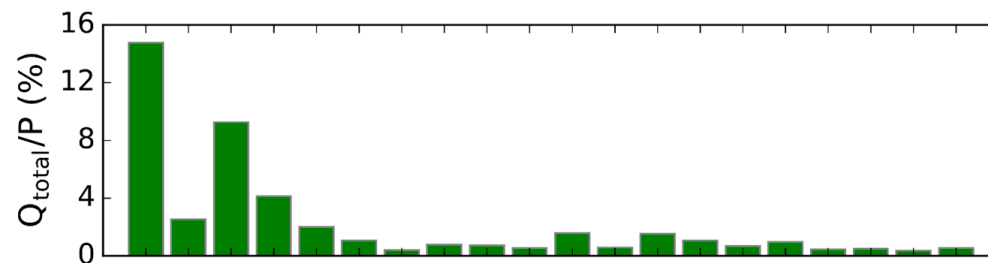

(e)

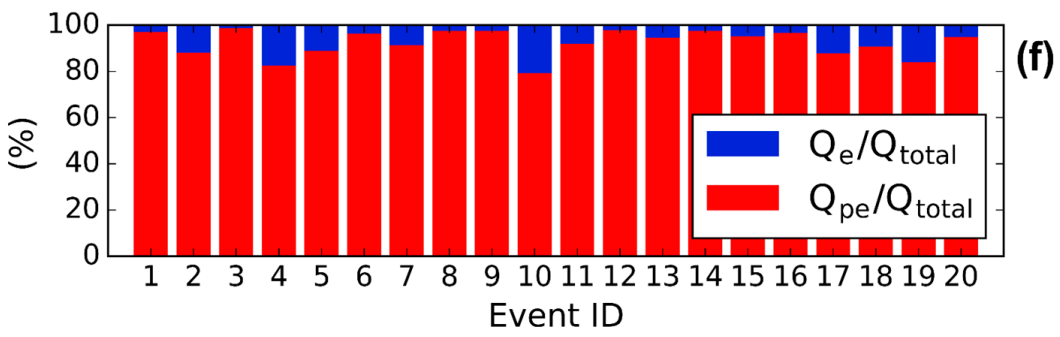

Figure 6. (a) Total precipitation per event $P,(\mathbf{b})$ mean rainfall intensity $P_{\text {int }},(\mathbf{c})$ initial soil moisture at the toeslope $S T$ in 5 and $30 \mathrm{~cm}$ depths, (d) initial soil moisture at the footslope $S F$ in 5 and $30 \mathrm{~cm}$ depths, (e) runoff coefficient $\frac{Q_{\text {total }}}{P}$ and (f) event water fraction $\frac{Q_{e}}{Q_{\text {total }}}$ and pre-event water fraction $\frac{Q_{p e}}{Q_{\text {total }}}$ of the 20 precipitation events. 
Initial soil moisture at the toeslope position showed an increasing trend over the sampling events at both, 5 and $30 \mathrm{~cm}$ soil depths (Figure 6c). ST5 ${ }_{\text {ini }}$ values were lower than those in $S T 30_{\text {ini }}$ until event \#7, and subsequently reached slightly higher values over the last events. By contrast, the initial soil moisture at the footslope was quite stable with a slight decrease over the sampling events at $30 \mathrm{~cm}$ depth, whereas an increasing trend with variation in between was observed at $5 \mathrm{~cm}$ depth (Figure $6 \mathrm{~d}$ ).

The runoff coefficient was relatively low, less than $2 \%$ for most of the events and with a mean of $2.2 \pm 3.5 \%$ (Figure $6 \mathrm{e}$ ). The highest runoff coefficient amounted to $14.8 \%$ at event $\# 1$, with a total precipitation input of only $1 \mathrm{~mm}$ but with a relatively high $S F 5_{\text {ini }}$ of around $13 \%$. The overall trend of runoff coefficient across the events showed that the events with relatively higher total precipitation did not necessarily result in higher rainfall-runoff ratios. Very low runoff coefficients $(<1 \%)$ were observed even at events with the highest total precipitation (i.e., event \#7 and \#19), and distinctly different values for $S F 5_{i n i}, S T 5_{i n i}$, and $S T 30_{i n i}$.

The event water fraction in total runoff was also relatively low for the 20 events and varied from 1.4 to a maximum of $20.8 \%$ ( $7.6 \pm 5.6 \%$ ). Only three events exceeded a value of $15 \%$, and on average, $92.4 \pm 5.6 \%$ of the discharge contained pre-event water (Figure $6 \mathrm{f}$ ). Lowest event water fractions (i.e., less than 3\%) were observed for events with low total precipitation inputs (less than $1 \mathrm{~mm}$ ), whereas highest event water fractions (i.e., more than $15 \%$ ) were observed for events with the total precipitation higher than $1.5 \mathrm{~mm}$.

Figure $7 \mathrm{a}, \mathrm{b}$ shows the maximum event water fraction $F_{E_{\max }}$ in stream water and groundwater across the 20 events. $F_{E_{\max }}$ ranged from 3.3 to $74.5 \%$ (20.6 $\left.\pm 17.2 \%\right)$ and from 3.1 to $86.3 \%(21.4 \pm 18.95 \%)$ in SW1 and SW2, respectively. Despite a slightly higher $F_{E_{\max }}$ at SW2 within most of the events, the difference between $F_{E_{\max }}$ of SW1 and SW2 was insignificant for most of the events (3.4\%, mean absolute difference). The highest $F_{E_{\max }}$ in the stream water was recorded at event \#19 with the highest total precipitation $P$ among all events $(19.6 \mathrm{~mm})$. For the remaining events, $F_{E_{\max }}$ was less than $50 \%$. Those $F_{E_{\max }}$ of stream water with higher values than the mean were observed at the events with $P$ higher than $1.4 \mathrm{~mm}$. At those events, in which $F_{E_{\max }}$ in groundwater was higher than the mean values, $F_{E_{\max }}$ in the stream water was also higher than the mean values (i.e., event \#2,\#10,\#15, \#18, and \#19; only exception was event \#17). The highest $F_{E_{\max }}$ in GW1 and GW2 was observed at event \#19, whereas the highest $F_{E_{\max }}$ in GW3 was quantified for event \#15. Differences between $F_{E_{\max }}$ of groundwater sources were marginal within most of the events. However, groundwater at the toeslope (GW1 and GW2) reached on average slightly higher $F_{E_{\max }}$ than the at the footslope (GW3).

Relatively large uncertainties of maximum event water fraction of $20 \%$ and more existed at events $\# 15, \# 18, \# 19$, and \#20 (Figure 7a,b) due to the large temporal variation of isotope values in precipitation and concurrent small differences between the isotopic composition of event and pre-event water. For the remaining events, the uncertainty was on average roughly $6 \%$ and $5 \%$ for stream water and groundwater, respectively.

The response time of maximum event water fraction $T_{F_{E \max }}$ ranged from $0.3 \mathrm{~h}$ to $24 \mathrm{~h}$ and $0.6 \mathrm{~h}$ to $33 \mathrm{~h}$ in stream water and groundwater, respectively (Figure $7 \mathrm{c}, \mathrm{d})$. On average, the event water fraction reached its maximum after $6 \mathrm{~h}$ in the stream water (i.e., SW1 and SW2). Differences between $T_{F_{E_{\max }}}$ in the two stream water sources were small ( $1.3 \mathrm{~h}$ mean absolute difference), except at event \#12, \#17, and \#20, at which the differences were larger than $5 \mathrm{~h}, 2 \mathrm{~h}$, and $3 \mathrm{~h}$, respectively. In comparison, the event water fractions in groundwater at the toeslope (GW1 and GW2) and the footslope (GW3) took a little longer to reach their maxima with 7-8 h. The longer response times in the stream water (i.e., at event $\# 2, \# 7, \# 15$, and \#19) as well as in the groundwater (i.e., at event \#2,\#17, and \#19) were observed at times when $F_{E_{\max }}$ was above its mean value. 

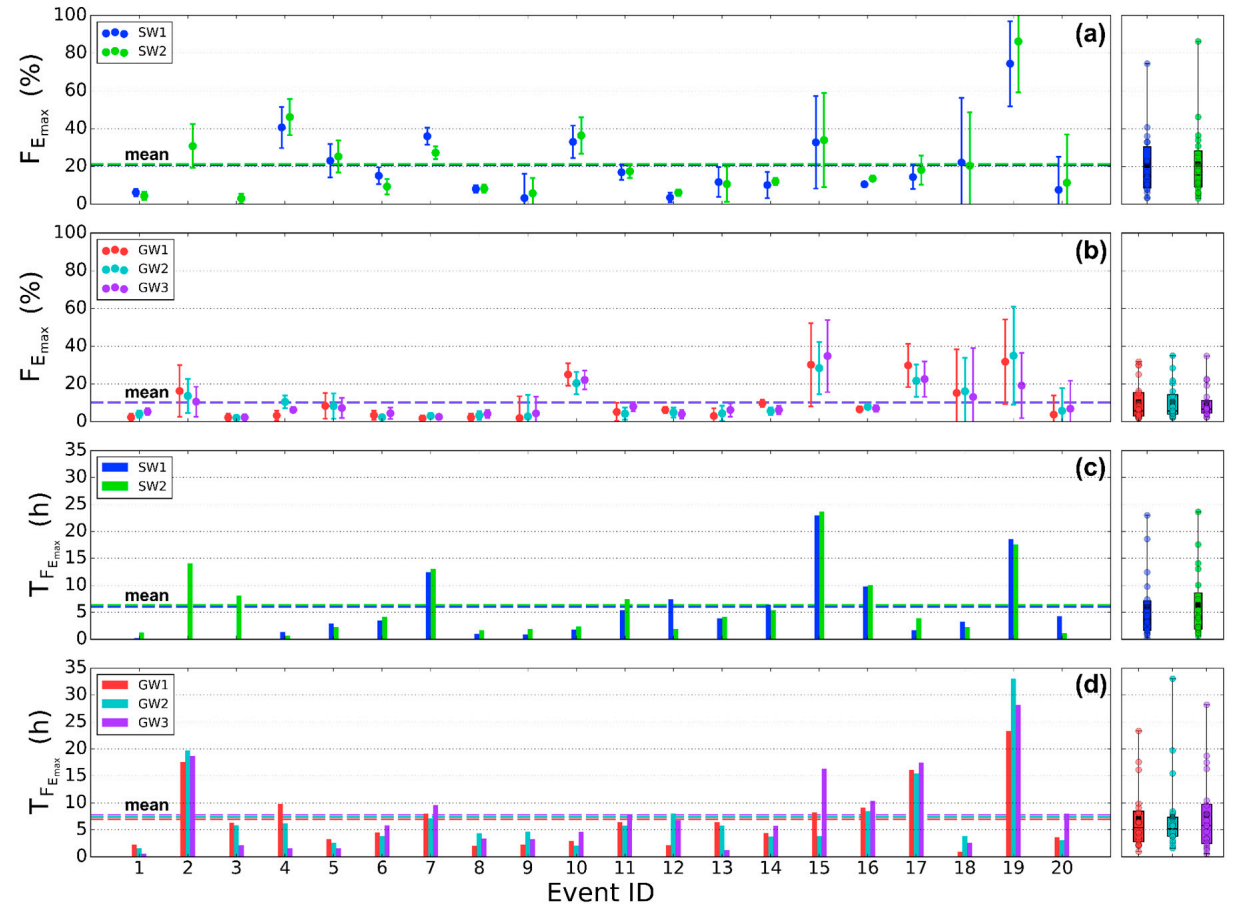

Figure 7. (a,b) Maximum event water fraction $F_{E_{\max }}$ for stream water (SW) and groundwater (GW) sources, including the uncertainty of estimations (error bars) and (c,d) response time of maximum event water fraction $T_{F_{E_{\max }}}$ for the same water sources. SW1 was not sampled at event \#2 and \#3. Boxplots (right panels) represent the interquartile range, black bars the median, black squares the mean and the whiskers the range of all 20 events.

\subsection{Correlations of Hydrometrics}

In order to investigate the role of precipitation and antecedent wetness conditions on discharge characteristics, maximum event water fraction and response time, we tested their correlations (Table 2). Event water contribution increased significantly with the precipitation amount. In turn, total event water volume $Q_{e}$ and event water fraction in total runoff $\frac{Q_{e}}{Q_{\text {total }}}$ correlated positively with precipitation amount $P$, whilst total pre-event water volume $Q_{p e}$ was strongest related to the initial discharge $Q_{i n i}$. No significant correlation was found for any of the soil moisture characteristics at the toeslope and discharge characteristics. By contrast, footslope soil moisture in deeper soil layers indicated a significant impact on total pre-event water contribution and the runoff coefficient.

Maximum event water fraction $F_{E_{\max }}$ in the stream water increased with the amount and duration of precipitation. $F_{E_{\max }}$ in groundwater was also related to the precipitation amount but with a less strong correlation. Particularly noteworthy was the importance of initial soil moisture conditions at the toeslope.

The response times $T_{F_{E_{\max }}}$ of GW1 and GW3 correlated moderately with total precipitation similar to $T_{F_{E_{\max }}}$ of SW1 and GW3 with precipitation duration and initial soil moisture of $70 \mathrm{~cm}$ depth at the toeslope (Table 2). No other significant correlations were established for any of the hydrometrics listed in Table 1. Nevertheless, we observed a clear two-state system with respect to the mean precipitation intensity $P_{\text {int }}$ (Figure 8). In the first state, no relationship could be depicted between $T_{F_{E_{\max }}}$ and $P_{\text {int }}$. After a certain threshold of $P_{\text {int }}$, the system swapped into a second state, at which $T_{F_{E_{\max }}}$ decreased with increasing $P_{\text {int }}$. In order to identify the threshold, we calculated the Spearman rank correlation between $T_{F_{E_{\max }}}$ and $P_{\text {int }}$ by leaving out one event after another starting from the event with the lowest $P_{\text {int }}$. The $P_{\text {int }}$ where we found the highest Spearman rank correlation coefficient was considered as the threshold. The Spearman rank correlation coefficients ranged between -0.99 and $-0.88(p<0.001)$ for 
all water sources. The threshold values were $0.47 \mathrm{~mm} \mathrm{~h}^{-1}$ for SW1, SW2, GW2, and GW3 and $0.44 \mathrm{~mm}$ $\mathrm{h}^{-1}$ for GW1 (Figure 8).

Table 2. Spearman rank correlation coefficients $(p)$ for the relationships of precipitation and antecedent wetness characteristics with discharge characteristic, maximum event water fraction and its response time (see Table 1 for acronyms). Green bolded cells represent statistically significant correlations with $p<0.05$.

\begin{tabular}{|c|c|c|c|c|c|c|c|c|c|c|}
\hline & $P$ & $T$ & $P_{\text {int }}$ & $Q_{i n i}$ & $S T 5_{i n i}$ & $S T 30_{\text {ini }}$ & $S T 70_{i n i}$ & $S F 5_{i n i}$ & $S F 30_{i n i}$ & $S F 70_{i n i}$ \\
\hline$Q_{\text {total }}$ & 0.54 & 0.10 & 0.33 & 0.69 & -0.39 & -0.30 & -0.37 & -0.38 & 0.43 & 0.44 \\
\hline$Q_{e}$ & 0.73 & 0.29 & 0.23 & 0.53 & -0.36 & -0.25 & -0.34 & -0.25 & 0.28 & 0.33 \\
\hline$Q_{p e}$ & 0.48 & 0.05 & 0.37 & 0.74 & -0.43 & -0.36 & -0.44 & -0.41 & 0.46 & 0.45 \\
\hline$\frac{Q_{\text {total }}}{P}$ & -0.39 & -0.53 & 0.17 & 0.49 & -0.42 & -0.39 & -0.32 & -0.38 & 0.59 & 0.48 \\
\hline$\frac{Q_{e}}{Q_{\text {total }}}$ & 0.64 & 0.41 & -0.06 & 0.05 & -0.04 & 0.02 & -0.04 & 0.04 & -0.10 & 0.00 \\
\hline$\frac{Q_{p e}}{Q_{\text {total }}}$ & -0.64 & -0.41 & 0.06 & -0.05 & 0.04 & -0.02 & 0.04 & -0.04 & 0.10 & 0.00 \\
\hline$F_{E_{\max }}$ SW1 & 0.75 & 0.58 & -0.12 & 0.25 & -0.18 & -0.17 & -0.10 & -0.29 & -0.14 & 0.05 \\
\hline$F_{E_{\max }}$ SW2 & 0.75 & 0.56 & -0.06 & -0.01 & 0.03 & 0.01 & 0.09 & -0.07 & -0.21 & -0.09 \\
\hline$F_{E_{\max }} \mathrm{GW} 1$ & 0.46 & 0.33 & -0.20 & -0.27 & 0.47 & 0.46 & 0.50 & 0.26 & -0.42 & -0.18 \\
\hline$F_{E_{\max }} \mathrm{GW} 2$ & 0.52 & 0.44 & -0.20 & -0.21 & 0.46 & 0.48 & 0.49 & 0.34 & -0.34 & -0.07 \\
\hline$F_{E_{\max }} \mathrm{GW} 3$ & 0.45 & 0.30 & -0.17 & -0.28 & 0.50 & 0.46 & 0.45 & 0.36 & -0.43 & -0.23 \\
\hline$T_{F_{E_{\max }}} \mathrm{SW} 1$ & 0.32 & 0.69 & -0.42 & -0.27 & 0.18 & 0.24 & 0.51 & -0.15 & -0.33 & -0.11 \\
\hline$T_{F_{E_{\max }}} \mathrm{SW} 2$ & 0.31 & 0.34 & -0.13 & -0.08 & 0.03 & -0.03 & 0.13 & -0.26 & -0.23 & -0.16 \\
\hline$T_{F_{E_{\max }}} \mathrm{GW} 1$ & 0.53 & 0.39 & -0.11 & 0.11 & 0.03 & 0.02 & 0.01 & -0.16 & 0.03 & 0.08 \\
\hline$T_{F_{E_{\max }}}$ GW2 & 0.19 & 0.43 & -0.26 & -0.01 & 0.01 & -0.03 & -0.15 & -0.04 & -0.13 & 0.00 \\
\hline$T_{F_{E_{\max }}}$ GW3 & 0.53 & 0.45 & -0.13 & -0.37 & 0.38 & 0.23 & 0.15 & 0.15 & -0.38 & -0.33 \\
\hline
\end{tabular}
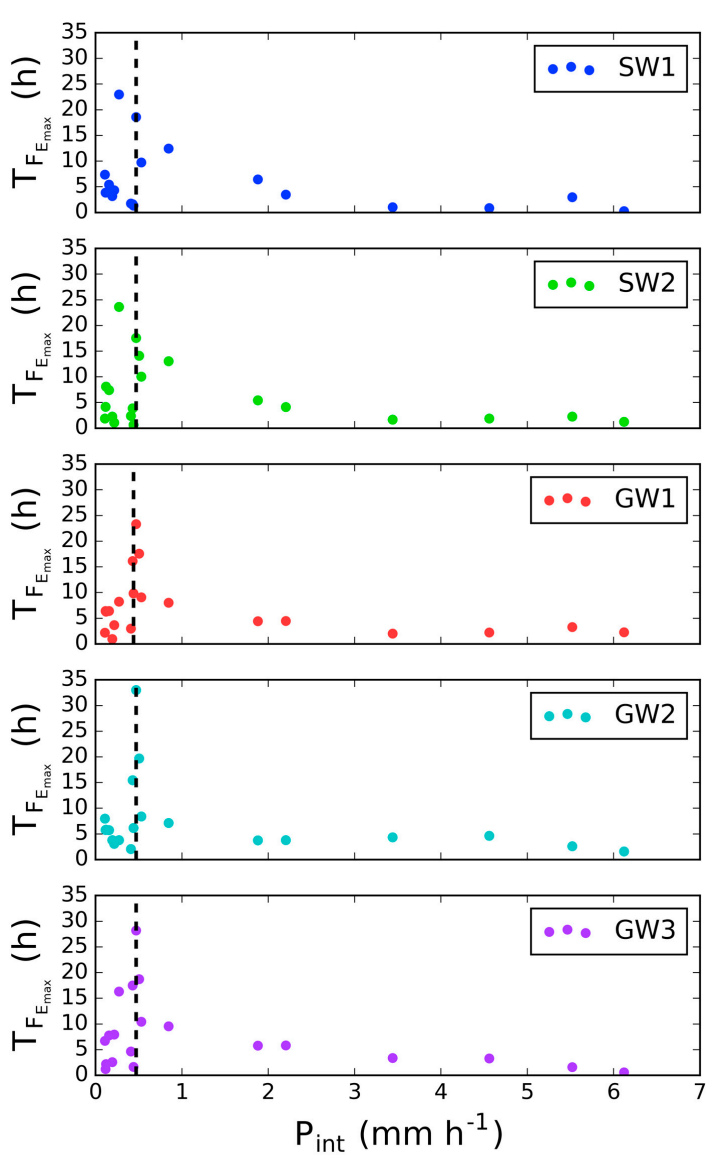

Figure 8. Response time $T_{F_{E_{m a x}}}$ of stream water and groundwater sources versus mean precipitation intensity $P_{\text {int }}$. The dashed line is the threshold, at which the response time decreased with increasing mean precipitation intensity. The threshold value was $0.47 \mathrm{~mm} \mathrm{~h}^{-1}$ for SW1, SW2, GW2, and GW3 and $0.44 \mathrm{~mm} \mathrm{~h}^{-1}$ for GW1. 


\section{Discussion}

\subsection{The Schwingbach is Highly Responsive to Precipitation}

Our findings show that the short-term response behavior observed in the previous studies in the SEO [16,17], is reflected in the isotopic signatures of stream water and groundwater. The isotopic responses in stream water and groundwater during the precipitation events often disclosed a rapid mixing of water in the sampling sources with event water indicating that the Schwingbach is a highly responsive catchment to incoming precipitation. The results reported that the average response time was $6 \mathrm{~h}$ in stream water and $7 \mathrm{~h}$ and $8 \mathrm{~h}$ for groundwater at the toeslope and footslope, respectively. Capturing event-based isotopic variation in stream water and groundwater emphasized the advantage of high-resolution sampling of multiple sources, giving insight into catchment response and runoff generation mechanisms. Firstly, the automated high-resolution sampling revealed the fine-scale hydrological responses of the stream water and groundwater, which could not be captured with manual isotope sampling in the previous study [17]. Secondly, the high-resolution data constrained the interpretation of event water contribution derived from hydrograph separation by the continuous sampling of stream water. Thirdly, sampling of groundwater along the stream water, showed that the groundwater response times, particularly at the toeslope, were close to the stream water response times. This underlines the linkage between stream water and shallow subsurface flow and consequently, the vital role of shallow subsurface flow in runoff generation in the Schwingbach.

\subsection{Pre-Event Water Dominates Runoff Generation}

Tracer-based hydrograph separations indicated that more than $79 \%$ of runoff consisted of pre-event water. Due to the highly permeable soils, the contribution of overland flow was negligible and hence precipitation infiltrated to the subsurface and mobilized pre-event water. Similar findings were reported in previous studies in other catchments, where pre-event water was also the major contributor to streamflow [7,24-26].

The runoff coefficients we found were very low (mean of $2.2 \%$ ). Low runoff coefficients are mainly a result of high soil permeability and dry catchment wetness conditions [27]. The high porosity of the soils in the upper layers of meadows and arable land (i.e., silty sand), as well as the extremely dry conditions in summer 2018, were likely reasons for the low runoff coefficients we measured. Other studies also reported low event runoff coefficients of less than $2 \%[28,29]$. They found that the high porosity of the soil, lack of anthropogenic effects such as soil compaction and dry antecedent wetness conditions were the main reasons for low runoff coefficients.

\subsection{Shallow Subsurface Flow Pathways Rapidly Deliver Water to the Stream}

The short response times of groundwater and stream water suggests the rapid movement of water vertically in the soil profile and in lateral downslope direction through shallow subsurface flow pathways. The short response times in the stream water (on average $6 \mathrm{~h}$ ) as well as in the groundwater, particularly at the toeslope with on average $7 \mathrm{~h}$, confirmed the linkage between stream water and shallow subsurface flow pathways. This linkage became likely stronger during events, at which maximum event water fractions in groundwater were above mean values such as event \#10 and \#19 (Figure 7a,b), and in turn, increased the event water fraction in total runoff (Figure 6f). Other studies also identified shallow subsurface as the dominant contributor to runoff generation $[5,7,25,30]$. Possible flow pathways leading to fast response times in stream water and groundwater can be vertical and lateral macropore flow pathways through unsaturated or partially saturated soil matrix [31-34]. During the dry summer of 2018, an extended crack network developed that had the potential to act as a drainage system. Water transmission can be very high through this vertically-oriented continuous network of macropores, even higher than rainfall intensities [33]. We conclude this to have happened in our system in view of the short response times we found in the groundwater. Furthermore, the relatively flat areas at the toeslope and the stream banks likely contributed to the rapid transmission of 
water. These areas have the potential to quickly saturate, store water, and rapidly release water to the stream network even during small precipitation events $[35,36]$. This assumption was supported by the distinct response of shallow soil moisture to precipitation events at the toeslope, which was not clearly visible at the footslope.

\subsection{Variable Controls of Runoff Generation}

Total event water volume and event water fraction in total runoff correlated positively with total event precipitation, pointing out that event water contribution increased with the precipitation amount (Table 2). Our results are consistent with previous studies, which also reported growing event water contribution with rising precipitation amounts $[4,5,7,10]$. Higher precipitation amounts led to an increase of maximum event water fraction, total event water volume, and event water fraction in total runoff. This suggests that the maximum event water fraction can be considered as a qualitative proxy to indicate the overall contribution of event water to runoff. The positive correlation of the maximum event water fraction in groundwater sources with precipitation amount and initial soil moisture at the toeslope underlined that not only the higher precipitation amount led to an increase of event water contribution but also that wetter conditions at the toeslope facilitated groundwater recharge mechanisms to switch on.

Total pre-event volume correlated moderately with total precipitation amount (Table 2) suggesting that increasing precipitation led to the mobilization of pre-event water. Albeit the rising total pre-event water volume, the pre-event water fraction in total runoff decreased, indicating the gaining importance of event water contribution at the same time. Wetter antecedent conditions often lead to an increase of pre-event water contribution $[4,5,7,9,10]$. Despite significant correlations of initial discharge and initial soil moisture of deeper layers at the footslope with total pre-event volume, we did not observe significant correlations between pre-event water fraction in total runoff and antecedent wetness hydrometrics in our system. Moreover, for catchments where pre-event water prevails in runoff generation, it is usually expected that antecedent wetness conditions show a major influence on the runoff coefficient. Although we detected significant correlations of the runoff coefficient with storm duration and antecedent wetness conditions in the Schwingbach, correlations were not strong and in the case of soil moisture conditions at the toeslope, they were even insignificant. This could be due to the dry and warm weather conditions during the study period, which resulted in only a small range of antecedent wetness conditions impacting the correlation analysis. Therefore, we conclude that pre-event water contribution was only moderately affected by precipitation amount, whereas under extremely dry conditions such as in the year 2018, the antecedent wetness was too low to impact the pre-event water contribution.

With a closer look at the response time variation with respect to the mean precipitation intensity (Figure 8), we detected a threshold of mean precipitation intensity, at which the response time behavior changed. Whereas there was no clear pattern before the threshold, the response times in stream water and groundwater decreased with increasing mean precipitation intensity after the threshold. This suggests that an increase in the mean precipitation intensity after a certain precipitation sum enhanced infiltration and that water rapidly drained causing event water fraction to reach its peak faster. Surprisingly, this threshold was very low with only $0.5 \mathrm{~mm} \mathrm{~h}^{-1}$, from where rainfall intensity likely controlled the initiation of macropore flow. It underlines that macropore networks governed flow control beyond the threshold. For mean precipitation intensities lower than the threshold, the trigger was not strong enough to control the response behavior.

\section{Conclusions}

Here we reported on high temporal resolution (20-min intervals) measurements of stable isotopes from groundwater, stream water, and precipitation to investigate the response of runoff components and the underlying controlling factors of precipitation and antecedent wetness characteristics. The 
analysis focused on 20 precipitation events in the Schwingbach Environmental Observatory (SEO) in Germany.

We conclude that high temporal resolution sampling of multiple sources, especially in systems with rapid hydrological responses, has a large potential to gain further insight into the runoff generation process. High temporal resolution sampling uncovered the event-based isotopic variation in stream water and groundwater and helped to constrain event and pre-event water contribution. The results of this investigation stress the importance of shallow subsurface flow contribution to the runoff in headwater systems. The sampling of groundwater in different hillslope positions and under different land uses increased the spatial resolution and led to better identify the main flow pathways during rapid delivery of water to the stream. We suggest that further studies be carried out over longer periods and that different land uses and slopes be taken into account in varying weather conditions.

Supplementary Materials: The following are available online at http://www.mdpi.com/2073-4441/12/2/565/s1, Table S1: Precipitation, antecedent wetness and discharge characteristics for the 20 events, Table S2: Maximum event water fraction $F_{E_{\max }}$, uncertainty of maximum event water fraction $W_{F_{E}}$ and response time $T_{F_{E_{\max }}}$ of stream water and groundwater sources derived from $\delta^{2} \mathrm{H}$ values for the 20 events, Table S3: Maximum event water

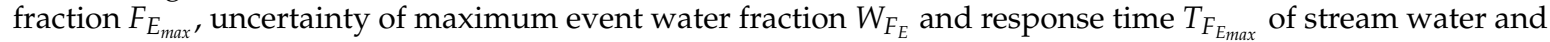
groundwater sources derived from $\delta^{18} \mathrm{O}$ values for the 20 events.

Author Contributions: Conceptualization, A.S., L.B., P.K., D.W.; methodology, P.K., D.W., A.S.; software, P.K., A.S.; validation, A.S., L.B., P.K.; formal analysis, A.S.; investigation, A.S.; resources, A.S., L.B., P.K., D.W.; data curation, A.S., P.K.; writing-original draft preparation, A.S.; writing-review and editing, L.B., P.K.; visualization, A.S.; supervision, L.B., P.K.; project administration, L.B.; funding acquisition, L.B. All authors have read and agreed to the published version of the manuscript.

Funding: This research received no external funding.

Conflicts of Interest: The authors declare no conflict of interest.

\section{References}

1. Klaus, J.; McDonnell, J.J. Hydrograph separation using stable isotopes: Review and evaluation. J. Hydrol. 2013, 505, 47-64. [CrossRef]

2. Shanley, J.B.; Kendall, C.; Smith, T.E.; Wolock, D.M.; McDonnell, J.J. Controls on old and new water contributions to stream flow at some nested catchments in Vermont, USA. Hydrol. Process. 2002, 16, 589-609. [CrossRef]

3. Šanda, M.; Sedlmaierová, P.; Vitvar, T.; Seidler, C.; Kändler, M.; Jankovec, J.; Kulasová, A.; Paška, F. Pre-event water contributions and streamwater residence times in different land use settings of the transboundary mesoscale Lužická Nisa catchment. J. Hydrol. Hydromech. 2017, 65, 154-164. [CrossRef]

4. Pellerin, B.A.; Wollheim, W.M.; Feng, X.; Vörösmarty, C.J. The application of electrical conductivity as a tracer for hydrograph separation in urban catchments. Hydrol. Process. 2008, 22, 1810-1818. [CrossRef]

5. James, A.L.; Roulet, N.T. Antecedent moisture conditions and catchment morphology as controls on spatial patterns of runoff generation in small forest catchments. J. Hydrol. 2009, 377, 351-366. [CrossRef]

6. Fischer, B.M.C.; Stähli, M.; Seibert, J. Pre-event water contributions to runoff events of different magnitude in pre-alpine headwaters. Hydrol. Res. 2017, 48, 28-47. [CrossRef]

7. Von Freyberg, J.; Studer, B.; Rinderer, M.; Kirchner, J.W. Studying catchment storm response using event- and pre-event-water volumes as fractions of precipitation rather than discharge. Hydrol. Earth Syst. Sci. 2018, 22, 5847-5865. [CrossRef]

8. Renshaw, C.E.; Feng, X.; Sinclair, K.J.; Dums, R.H. The use of stream flow routing for direct channel precipitation with isotopically-based hydrograph separations: The role of new water in stormflow generation. J. Hydrol. 2003, 273, 205-216. [CrossRef]

9. Muñoz-Villers, L.E.; McDonnell, J.J. Runoff generation in a steep, tropical montane cloud forest catchment on permeable volcanic substrate. Water Resour. Res. 2012, 48. [CrossRef]

10. Penna, D.; van Meerveld, H.J.; Oliviero, O.; Zuecco, G.; Assendelft, R.S.; Dalla Fontana, G.; Borga, M. Seasonal changes in runoff generation in a small forested mountain catchment. Hydrol. Process. 2015, 29, 2027-2042. [CrossRef] 
11. McGlynn, B.L.; McDonnell, J.J.; Seibert, J.; Kendall, C. Scale effects on headwater catchment runoff timing, flow sources, and groundwater-streamflow relations. Water Resour. Res. 2004, 40. [CrossRef]

12. Kirchner, J.W.; Feng, X.; Neal, C.; Robson, A.J. The fine structure of water-quality dynamics: The (highfrequency) wave of the future. Hydrol. Process. 2004, 18, 1353-1359. [CrossRef]

13. Von Freyberg, J.; Studer, B.; Kirchner, J.W. A lab in the field: High-frequency analysis of water quality and stable isotopes in stream water and precipitation. Hydrol. Earth Syst. Sci. 2017, 21, 1721-1739. [CrossRef]

14. Heinz, E.; Kraft, P.; Buchen, C.; Frede, H.-G.; Aquino, E.; Breuer, L. Set Up of an Automatic Water Quality Sampling System in Irrigation Agriculture. Sensors 2014, 14, 212-228. [CrossRef] [PubMed]

15. Mahindawansha, A.; Breuer, L.; Chamorro, A.; Kraft, P. High-Frequency Water Isotopic Analysis Using an Automatic Water Sampling System in Rice-Based Cropping Systems. Water 2018, 10, 1327. [CrossRef]

16. Orlowski, N.; Lauer, F.; Kraft, P.; Frede, H.-G.; Breuer, L. Linking Spatial Patterns of Groundwater Table Dynamics and Streamflow Generation Processes in a Small Developed Catchment. Water 2014, 6, 3085-3117. [CrossRef]

17. Orlowski, N.; Kraft, P.; Pferdmenges, J.; Breuer, L. Exploring water cycle dynamics by sampling multiple stable water isotope pools in a developed landscape in Germany. Hydrol. Earth Syst. Sci. 2016, 20, 3873-3894. [CrossRef]

18. Vogel, M.M.; Zscheischler, J.; Wartenburger, R.; Dee, D.; Seneviratne, S.I. Concurrent 2018 Hot Extremes Across Northern Hemisphere Due to Human-Induced Climate Change. Earth's Future 2019, 7, 692-703. [CrossRef]

19. Eijkelkamp RBC Flumes. Available online: https://en.eijkelkamp.com/products/sensors-monitoring_uk/rbcflumes.html (accessed on 6 February 2020).

20. Wenzel, H.G., Jr.; Voorhees, M.L. Evaluation of the Urban Design Storm Concept; University of Illinois at Urbana-Champaign: Champaign, IL, USA, 1981.

21. Gaál, L.; Molnar, P.; Szolgay, J. Selection of intense rainfall events based on intensity thresholds and lightning data in Switzerland. Hydrol. Earth Syst. Sci. 2014, 18, 1561-1573. [CrossRef]

22. McDonnell, J.J.; Bonell, M.; Stewart, M.K.; Pearce, A.J. Deuterium Variations in Storm Rainfall: Implications for Stream Hydrograph Separation. Water Resour. Res. 1990, 26, 455-458. [CrossRef]

23. Genereux, D. Quantifying uncertainty in tracer-based hydrograph separations. Water Resour. Res. 1998, 34, 915-919. [CrossRef]

24. Buttle, J.M. Isotope hydrograph separations and rapid delivery of pre-event water from drainage basins. Prog. Phys. Geogr. 1994, 18, 16-41. [CrossRef]

25. McGlynn, B.L.; McDonnell, J.J. Quantifying the relative contributions of riparian and hillslope zones to catchment runoff. Water Resour. Res. 2003, 39. [CrossRef]

26. Jones, J.P.; Sudicky, E.A.; Brookfield, A.E.; Park, Y.-J. An assessment of the tracer-based approach to quantifying groundwater contributions to streamflow. Water Resour. Res. 2006, 42. [CrossRef]

27. Merz, R.; Blöschl, G. A regional analysis of event runoff coefficients with respect to climate and catchment characteristics in Austria. Water Resour. Res. 2009, 45. [CrossRef]

28. Blume, T.; Zehe, E.; Bronstert, A. Rainfall—runoff response, event-based runoff coefficients and hydrograph separation. Hydrol. Sci. J. 2007, 52, 843-862. [CrossRef]

29. Scherrer, S.; Naef, F.; Faeh, A.O.; Cordery, I. Formation of runoff at the hillslope scale during intense precipitation. Hydrol. Earth Syst. Sci. 2007, 11, 907-922. [CrossRef]

30. Brown, V.A.; McDonnell, J.J.; Burns, D.A.; Kendall, C. The role of event water, a rapid shallow flow component, and catchment size in summer stormflow. J. Hydrol. 1999, 217, 171-190. [CrossRef]

31. Beven, K.; Germann, P. Macropores and Water Flow in Soils. Water Resour. Res. 1982, 18, 1311-1325. [CrossRef]

32. McDonnell, J.J. A Rationale for Old Water Discharge Through Macropores in a Steep, Humid Catchment. Water Resour. Res. 1990, 26, 2821-2832. [CrossRef]

33. Weiler, M.; Naef, F. An experimental tracer study of the role of macropores in infiltration in grassland soils. Hydrol. Process. 2003, 17, 477-493. [CrossRef]

34. Jones, J.A.A. Soil piping and catchment response. Hydrol. Process. 2010, 24, 1548-1566. [CrossRef]

35. Sidle, R.C.; Tsuboyama, Y.; Noguchi, S.; Hosoda, I.; Fujieda, M.; Shimizu, T. Stormflow generation in steep forested headwaters: A linked hydrogeomorphic paradigm. Hydrol. Process. 2000, 14, 369-385. [CrossRef] 
36. Penna, D.; Meerveld, H.J.T.; Gobbi, A.; Borga, M.; Dalla Fontana, G. The influence of soil moisture on threshold runoff generation processes in an alpine headwater catchment. Hydrol. Earth Syst. Sci. 2011, 15, 689-702. [CrossRef] 